Fakultas Pertanian UNIVERSITAS TRIDINANTI

PALEMBANG

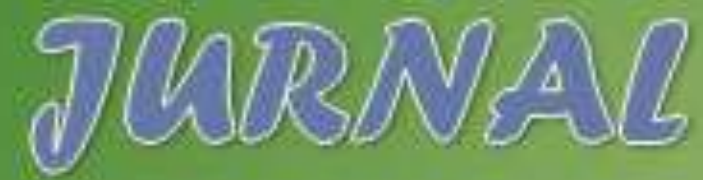

슬

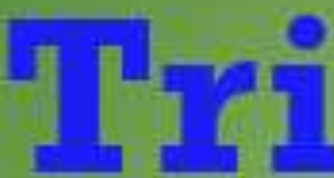


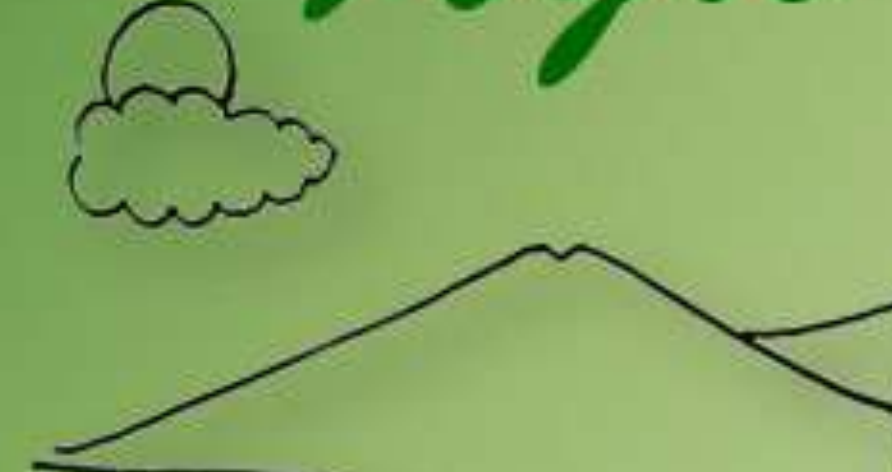


\section{Jurnal TRIAGRO}

FaKULTAS PERTAMLAO UNVERSITAS TRIDINARTI PAIEMRARG

\section{Dewan Redaksi}

Pelindung

Pembina

Pimpinan Umum

Ketua Penyunting

Penyunting Pelaksana

Penyunting Ahli

Dewan Redaksi

Distribusi \& Website
: Dr. Ir. Hj. Manisah MP (Rektor)

: Dr. Nasir Sp. M.Si

: Miranty Trinawaty SP. M.Si

: Dr.Ir.Nur Ahmadi

- Prof. Dr. Edizal M.S

- Dr. Ir. Nur Ahmadi

- Dr.Ir Faridatul Mukminah M.Sc

- Dr. Ir Ruarita RK. MP

: 1. Dr. Ir. Nurmayulis , MP (Universitas Sultan Ageng Tirtayasa)

2. Dr. Munajat, SP. M.Si (Universitas Baturaja)

:

- Ir. Setiawaty MP

- $\quad$ Ir. Meryanto, M.Si

- Ir. Rostian Nafery, M.Si

- Ir. Ursula Damayanti, MP

- Ir. Ekanovi Aktiva, MM

- Ir. Hj. Yuliantina Azka, MP

: Nova Tri Buyana, Sp 


\section{DAFTAR ISI}

1 PENGARUH PERBEDAAN JENIS MATA ENTRES DAN KLON TERHADAP PERTUMBUHAN BIBIT KARET (Hevea brasiliensis Muell Arg.)DI POLYBAG

Meriyanto, Bastani S., and Indah L

2 RESPON BEBERAPA VARIETAS PADI (Oriza Sativa L)TERHADAP PEMBERIAN BEBERAPA JENIS PUPUK DI TANAH PASANG SURUT

\section{8} Ida Aryani

PENGARUH PERLAKUAN BENIH DAN MEDIA TANAM TERHADAP

3 PERKECAMBAHAN DAN PERTUMBUHAN BENIH SALAK (Salacca edulis Reinw) DI POLIBEG

Zulkarnain Husny, Ridwan Hanan, Hendri

4 ANALISIS PEMASARAN BAHAN OLAH KARET (BOKAR) DAN PENDAPATAN PETANI KARET (Studi Kasus di Desa Surya Adi Kecamatan Mesuji Kabupaten Ogan Komering Ilir)

Nur Ahmadi, Gusti Fitriyana, Tri Sudoni.

5 KONTRIBUSI PENDAPATAN USAHATANI PADI LEBAK TERHADAP TOTAL PENDAPATAN KELUARGA (Kasus di Desa Arisan Musi Timur 33 Kecamatan Muara Belida Kabupaten Muara Enim)

Setiawati, Denny Herdian, Melda Santi

6 NALISIS HARGA POKOK DAN KEUNTUNGAN USAHATANI CABAI 46 MERAH BESAR (Capsicum Annuum L) DI DESA TALANG BULUH KECAMATANTALANG KELAPA KABUPATEN BANYUASIN

Ursula Damayanti, Denni Herdian 


\section{Pedoman Penulisan Artikel Ilmiah Jurnal TRIAgro Fakultas Pertanian Universitas Tridinanti Palembang}

1. Jurnal ini direncanakan terbit tiga kali dalam setahun, terbuka untuk umum yang ingin mempublikasikan hasil karyanya. Artikel yang ditulis meliputi hasil penelitian di bidang sains.

2. Semua naskah makalah disertai pernyataan bahwa naskah tersebut belum pernah diterbitkan sebelumnya oleh penerbit lain.

3. Setiap naskah yang diterima akan ditinjau/ditelaah oleh ahli dibidangnya sebelum diterbitkan.

4. Naskah tidak dapat diterima jika mengandung unsur politik, komersialisme dan subyektifitas yang berlebihan.

5. Simbol dan terminologi yang digunakan adalah simbol dan terminologi yang lazim digunakan di bidang keahlian masin-masing.

6. Penulis menyetujui untuk mengalihkan hak ciptanya ke redaksi, jika naskahnya diterima untuk diterbitkan.

7. Artikel ditulis dalam bahasa Indonesia atau Inggris. Minimal 10 halaman dan maksimal 15 halaman, termasuk daftar pustaka dan lampiran : ukuran kertas A4, spasi 1,5, margin kiri $4 \mathrm{~cm}$, margin kanan, atas dan bawah masing-masing $3 \mathrm{~cm}$, menggunakan Times New Roman Font 11.

8. Artikel diketik dengan program MS Word, penulis dimohon mengirimkan satu print out dan satu CD yang berisi artikel, cantumkan alamat email dan no telepon/hp penulis untuk keperluan konfirmasi tentang tulisan yang dikirimkan ke redaksi.

9. Artikel dilengkapi :

Abstrak tidak lebih dari 200 kata dengan kata-kata kunci, biodata singkat penulis dan identitas penelitian dicantumkan sebagai cat kaki pada halaman pertma artikel.

10. Penulisan daftar pustaka mengikuti penulisan yang baik dan benar 


\section{KATA PENGANTAR}

Terima kasih atas berkah Tuhan Yang Maha Kuasa dan Rahmat-Nya, maka Jurnal TriAgro Fakultas Pertanian Universitas Tridinanti Palembang ini dapat diterbitkan. Jurnal ini diharapkan dapat menampung informasi dunia pertanian modern dan menyebarkan informasi di lingkup pertanian baik secara umum maupun khusus, penerbitan jurnal ini diharapkan dapat menjadi sarana untuk menampung tulisan-tulisan ilmiah pertanian.

Dewan redaksi mengucapkan terima kasih kepada semua pihak yang telah memerikan bantuan teknis maupun non teknis untuk terbitnya jurnal TriAgro ini. Dewan redaksi sangat mengharapkan partisipasi peneliti untuk menyumbangkan tulisannya ke jurnal TriArgro ini guna menjaga kelancaran penerbitan, yaitu dua kali setahun.

Dewan redaksi mengucapkan terima kasih kepada Bapak/Ibu/Saudara yang telah berpartisipasi pada jurnal edisi ini. Semoga Jurnal ini dapat memberikan manfaat kepada Bapak/Ibu/Saudara semuanya. 


\title{
RESPON BEBERAPA VARIETAS PADI (Oriza Sativa L) TERHADAP PEMBERIAN BEBERAPA JENIS PUPUK DI TANAH PASANG SURUT
}

\author{
Ida Aryani* \\ *Dosen Tetap Fakultas Pertanian Universitas Pelembang \\ Email idadeni10@yahoo.com
}

\begin{abstract}
Ringkasan
Upaya meningkatkan produksi beras nasional terus dilakukan, salah satunya adalah dengan memanfaatkan lahan suboptimal yaitu lahan pasang surut yang terbentang luas di pesisir timur Sumatera Selatan. Keberhasilan pengelohan lahan pasang surut hendaknya dilakukan spesifik tergantung permasalahan yang ada di lapangan. Pemecahan masalah tidak bisa dilakukan secara persial, tetapi terintegrasi menggunakan varietas yang sesuai dan toleran serta perbaikan lingkungan tumbuh tanaman seperti pemupukan yang berimbang. Varietas padi lokal yang biasa digunakan petani di lahan pasang surut umumnya cukup toleran terhadap kendala - kendala seperti kemasaman dan kadar Fe tinggi, namun ratarata hasil padi lokal masih rendah. Rendahnya hasil padi lokal ini diperkirakan karena sifat genetik padi yang mempunyai potensi hasil yang memang tidak tinggi dan juga karena tidak tepatnya pemupukan yang dilakukan petani. Berdasarkan uraian di atas perlu kiranya mengadakan penelitian tentang respon beberapa varietas padi (Oryza sativa L.) terhadap pemberian jenis pupuk pada tanah pasang surut. Yang dilakukan pada bulan Januari - April 2016. Dilaksanakan di Screen House Fakultas Pertanian Universitas Palembang. Penelitian ini bertujuan untuk mengetahui dan mendapatkan respon terbaik beberapa varietas padi (Oryza sativa L.) terhadap pemberian jenis pupuk di lahan pasang surut. Penelitian ini dilakukan dengan menggunakan Rancangan Acak Lengkap (RAL) faktorial dengan 9 (sembilan) kombinasi perlakuan yang diulang 3 (tiga) kali. Adapun faktor perlakuannya adalah Faktor I. Varietas Padi (V): $V_{1}=$ Aek Sibundong, $\mathrm{V}_{2}=$ Jati Luhur, $\mathrm{V}_{3}=$ Inpago 7 . Faktor II. Jenis Pupuk (P) $\mathrm{P}_{0}=$ Pupuk anorganik (N : $250 \mathrm{Kg} / \mathrm{ha} . \mathrm{P}: 150 \mathrm{Kg} / \mathrm{ha} . \mathrm{K}: 100 \mathrm{Kg} / \mathrm{ha}) . \mathrm{P}_{1}=$ Kompos jerami padi (3 Ton/ha). $\mathrm{P}_{2}=$ Pupuk hayati (10 cc/liter). Parameter yang diamati dalam penelitian ini adalah tinggi tanaman, jumlah anakan maximum, jumlah anakan produktif, jumlah gabah per malai, jumlah gabah isi per malai, persentase gabah hampa, berat 100 butir, berat gabah kering dan berat berangkasan kering. Dari hasil penelitian yang telah dilakukan dapat diambil kesimpulan, yaitu 1. Varietas padi jatiluhur menunjukan pertumbuhan dan produksi yang lebih baik dibandingkan dengan varietas lain 2. Pemberian pupuk anorganik menunjukan pertumbuhan dan produksi yang lebih baik dibandingkan dengan pemberian pupuk hayati dan pupuk kompos jerami padi.
\end{abstract}




\section{PENDAHULUAN}

\section{A. Latar Belakang}

Padi (Oryza Sativa L) merupakan komoditas yang penting dan strategis, dimana kebutuhan akan konsumsi beras ini terus meningkat seiring dengan meningkatnya jumlah penduduk, hal ini mengisyaratkan perlunya peningkatan produksi beras di Indonesia.

Upaya meningkatkan produksi beras nasional terus dilakukan, salah satunya adalah dengan memanfaatkan lahan suboptimal yaitu lahan pasang surut yang terbentang luas di pesisir timur Sumatera Selatan.Luas padi sawah pasang surut pada tahun 2011 di Sumatera Selatan adalah 255.087 ha (BPS Sumsel, 2012) yang sebagian besar termasuk dalam wilayah Kabupaten Banyuasin. Hasil rata-rata padi sawah pasang surut di Kabupaten Banyuasin pada tahun 2011 yaitu 4,41 ton/ha (BPS Banyuasin, 2012) adalah jauh lebih rendah dari hasil rata-rata padi sawah irigasi di Kabupaten Ogan Komering Ulu Timur (OKUT) yaitu 6,40 ton/ha (BPS OKUT, 2012).

Karakteristik lahan yang menjadi masalah dalam pengembangan pertanian dilahan pasang surut meliputi fluktuasi rejim air, beragamnya kondisi fisiko-kimia tanahnya, tingginya kemasaman tanah dan asam organik pada lahan gambut, adanya zat beracun, intrusi air garam, dan rendahnya kesuburan alami tanahnya. Khusus untuk lahan sulfat masa meliputi kemasaman tanah dan air sangat tinggi, kandungan aluminium ( $\mathrm{Al})$, besi $(\mathrm{Fe})$ dan hidrogen sulfida (H2S) tinggi, dan ketersediaan unsur hara terutama $\mathrm{P}$ dan $\mathrm{K}$ rendah. Sedangkan untuk lahan gambut meliputi kemasaman tanah dan air tinggi, ketersediaan unsur hara makro dan mikro terutama $\mathrm{P}, \mathrm{K}, \mathrm{Zn}, \mathrm{Cu}$ dan Bo rendah, dan daya sangga tanah rendah (Nazemi et al, 2012).
Keberhasilan pengelohan lahan pasang surut hendaknya dilakukan spesifik tergantung permasalahan yang ada di lapangan. Pemecahan masalah tidak bisa dilakukan secara persial, tetapi terintegrasi menggunakan varietas yang sesuai dan toleran serta perbaikan lingkungan tumbuh tanaman seperti pemupukan yang berimbang. Varietas padi lokal yang biasa digunakan petani di lahan pasang surut umumnya cukup toleran terhadap kendala kendala seperti kemasaman dan kadar Fe tinggi, namun rata-rata hasil padi lokal masih rendah. Rendahnya hasil padi lokal ini diperkirakan karena sifat genetik padi yang mempunyai potensi hasil yang memang tidak tinggi dan juga karena tidak tepatnya pemupukan yang dilakukan petani. Pemupukan yang dilakukan petani di lahan pasang surut umumnya hanya menggunakan pupuk buatan sedangkan penggunaan pupuk organik tidak dilakukan petani.

Pupuk anorganik merupakan pupuk buatan pabrik, berbahan dasar dari mineral dan udara. Bahan dasar pupuk nitrogen adalah nitogen dari udara, sedangkan pupuk $\mathrm{P}, \mathrm{K}, \mathrm{Ca}, \mathrm{Mg}$ dari tambang (Bank Pengetahuan Padi Indonesia, 2009). (dalam penelitian ini menggunakan pupuk Urea, Sp36 dan KCL)

Menurut Crawford (2003), kompos adalah hasil penguraian tidak lengkap dan dapat dipercepat secara artificial oleh populasi berbagai macam mikroba dalam kondisi lingkungan yang hangat, lembab, dan aerobik atau anaerobik (Crawford ,2003 dalam Aryantha, 2010). Kesuburan dan kegemburan tanah akan terjaga jika kita selalu menambahkan bahan organik, salah satunya kompos. Pemakaian kompos sangat dianjurkan karena dapat memperbaiki produktivitas tanah, baik secara fisik, kimia, maupun biologi tanah. Secara fisik, kompos bisa menggemburkan tanah; memperbaiki aerasi dan drainase; meningkatkan pengikatan antar-partikel dan kapasitas 


\section{JURNAL TRI $A G R O$}

mengikat air sehingga dapat mencegah erosi dan longsor; mengurangi tercucinya nitrogen terlarut serta memperbaiki daya olah tanah. (dalam penelitian ini menggunakan pupuk kompos jerami padi)

Pupuk hayati adalah mikrobia yang diberikan ke dalam tanah untuk meningkatkan pengambilan hara oleh tanaman dari dalam tanah atau udara. Umumnya digunakan mikrobia yang mampu hidup bersama (simbiosis) dengan tanaman inangnya. Keuntungan diperoleh oleh kedua pihak, tanaman inang mendapatkan tambahan unsur hara yang diperlukan, sedangkan mikrobia mendapatkan bahan organik untuk aktivitas dan pertumbuhannya. pupuk organik hayati yang digunakan pada penelitian ini adalah pupuk hayati yang mengandung mikroorganisme Azospirillum, $S p$ sebagai penambat $\mathrm{N}_{2}$.

Hasil penelitian Marlina et al (2013), menunjukkan bahwa tinggi tanaman 8 MST, jumlah anakan maksimum, jumlah anakan produktif, jumlah gabah isi per malai, berat 1000 butir dan produksi padi per petak terbaik diperoleh pada perlakuan pemberian pupuk hayati bio $\mathrm{P}+$ Azospirillum dengan varietas indragiri yaitu dengan produksi 305,67 g petak-1.

\section{PELAKSANAAN PENELITIAN}

\section{A. Tempat dan Waktu}

Penelitian ini akan dilaksanakan di Screen House Fakultas Pertanian Universitas Palembang Jln. Dharmapala Bukit Besar Palembang. Penelitian akan dilakukan pada bulan Januari 2016 sampai dengan April 2016.

\section{B. Bahan dan Alat}

Bahan -bahan yang digunakan dalam penelitian ini adalah : 1) tanah, 2) bahanbahan untuk pengambilan contoh tanah, 3) bahan-bahan untuk analisis $\mathrm{pH}$ tanah, kandungan $\mathrm{C}, \mathrm{N}$ dan $\mathrm{P}$ tanah. Sedangkan alat-alat yang digunakan adalah: 1) alat-alat
Vol 1 No.2 Juli-Desember 2016

Sennang et al (2012) baik yang terdapat dalam pupuk hayati dapat meningkatkan penyerapan NPK dibandingkan dengan kontrol. Gofar et al (2009), pada tanaman padi rawa lebak menyebabkan pertumbuhan hasil padi meningkat.

Berdasarkan uraian di atas perlu kiranya mengadakan penelitian tentang respon beberapa varietas padi (Oryza sativa L.) terhadap pemberian jenis pupuk pada tanah pasang surut.

\section{B. Tujuan}

Adapun tujuan dari penelitian ini adalah untuk mendapatkan respon beberapa varietas padi (Oryza sativa L.) terhadap pemberian jenis pupuk di lahan pasang surut.

\section{Hipotesis}

Diduga pemberian pupuk hayati dengan dosis $10 \mathrm{cc}$ perliter air $\left(\mathrm{P}_{2}\right)$ dapat memberikan pertumbuhan dan produksi yang terbaik terhadap varietas tanaman padi aek sibundong $\left(\mathrm{V}_{1}\right)$ pada tanah pasang surut.

untuk mengambil contoh tanah, 2) alat-alat untuk menyimpan contoh tanah yang akan di analisis, 3) alat-alat analisis $\mathrm{pH}$, kandungan $\mathrm{C}, \mathrm{N}$ dan $\mathrm{P}$ tanah.

\section{Metode Penelitian}

Rancangan Acak Lengkap (RAL) faktorial dengan 9 (sembilan) kombinasi perlakuan yang diulang 3 (tiga) kali. Adapun faktor perlakuannya adalah :

Faktor I. Varietas Padi (V) : $\mathrm{V}_{1}=$ Aek Sibundong, $V_{2}=$ Jati Luhur, $V_{3}=$ Inpago 7

Faktor II. Jenis Pupuk (P) : $\mathrm{P}_{0}=$ Pupuk anorganik (N : $250 \mathrm{Kg} / \mathrm{ha}), \mathrm{P}: 150 \mathrm{Kg} / \mathrm{ha} . \mathrm{K}$ : $100 \mathrm{Kg} / \mathrm{ha}), \mathrm{P}_{1}=$ Kompos jerami padi $(3$ Ton/ha), $\mathrm{P}_{2}=$ Pupuk hayati $(10 \mathrm{cc} / \mathrm{liter})$. 


\section{Analisis Statistik}

Data yang ddapat dari hasil penelitian di analisis secara statistik dengan menggunakan analisis keragaman (uji-f) seperti pada Tabel 1.

Tabel 1. Analisis keragaman Rancangan Acak Lengkap Faktorial

\begin{tabular}{|c|l|l|l|l|}
\hline $\begin{array}{c}\text { Sumber Keragaman } \\
\text { (SK) }\end{array}$ & \multicolumn{1}{|c|}{$\begin{array}{c}\text { Derajat }(\mathbf{D B}) \\
\text { Bebas }\end{array}$} & $\begin{array}{c}\text { Jumlah } \\
\text { Kuadrat (JK) }\end{array}$ & $\begin{array}{c}\text { Kuadrat } \\
\text { Tengah (KT) }\end{array}$ & \multicolumn{1}{|c|}{ F-hitung } \\
\hline Perlakuan VP & $\mathrm{VP}-1=\mathrm{V}_{1}$ & $\mathrm{JKP}$ & $\mathrm{JKP} / \mathrm{V}_{1}$ & $\mathrm{KTH} / \mathrm{KTG}$ \\
$\mathrm{V}$ & $\mathrm{V}-1=\mathrm{V}_{2}$ & $\mathrm{JKV}$ & $\mathrm{JKV} / \mathrm{V}_{2}$ & $\mathrm{KTV} / \mathrm{KTG}$ \\
$\mathrm{P}$ & $\mathrm{P}-1=\mathrm{V}_{3}$ & $\mathrm{JKP}$ & $\mathrm{JKP} / \mathrm{V}_{3}$ & $\mathrm{KTP} / \mathrm{KTG}$ \\
$\mathrm{I}$ & $(\mathrm{V}-1)(\mathrm{P}-1)=\mathrm{V}_{4}$ & $\mathrm{JKI}$ & $\mathrm{JKI} / \mathrm{V}_{4}$ & $\mathrm{KTI} / \mathrm{KTG}$ \\
Galat & $\mathrm{Vt}-\mathrm{V}_{1}=\mathrm{V}_{5}$ & $\mathrm{JKG}$ & $\mathrm{JKG} / \mathrm{V}_{5}$ & - \\
\hline Total & $(\mathrm{VP} . \mathrm{I}-1)=\mathrm{Vt}$ & $\mathrm{JKT}$ & - & - \\
\hline
\end{tabular}

Sumber: Hanafiah, K. A. (1990). Rancangan Percobaan, Teori dan Aplikasi. Rajawali Pers, Jakarta

Uji keragaman dilakukan dengan membandingkan F-hitung dengan F-tabel pada taraf uji $1 \%$ dan $5 \%$, apabila F-hitung lebih kecil dari F-tabel 5\%, maka perlakuan dinyatakan berpengarut tidak nyata, sedangkan bila F-hitung lebih besar dari tabel $5 \%$ tetapi lebih kecil dari $1 \%$ maka E. Cara Kerja

\section{Pembuatan Rumah Plastik/ Screen House}

Bahan-bahan yang dipakai dalam pembuatan Screen House dengan ukuran panjang $8 \mathrm{~m}$ dan lebar $6 \mathrm{~m}$.

\section{Pengisian Tanah Ke Dalam Pot}

Tanah ditimbang sebanyak $10 \quad \mathrm{Kg}$ kemudian dimasukkan ke dalam pot.

\section{Pemupukan}

Pemberian pupuk dilakukan dua hari sebelum dilakukan penanaman, dengan banyak pupuk yang diberikan pada setiap potnya sesuai dengan perlakuan. perlakuan dinyatakan berpengaruh nyata. Dan apabila F-hitung lebih besar dari $1 \%$, maka perlakuan dinyatakan berpengaruh sangat nyata. Untuk menguji tingkat ketelitian dari percobaan yang dilakukan digunakan koefisien keragaman (KK).

\section{Penanaman}

Benih padi ditanaman sebanyak 5 benih untuk setiap potnya, dengan kedalaman $2 \mathrm{~cm}$. Setelah 1 minggu dipilih 2 tanaman yaitu menunjukkan pertumbuhan seragam untuk dipelihara.

\section{Pemeliharaan}

Pemeliharaan meliputi penyiraman benih yang ditanam dalam pot yang dilakukan dua kali sehari pada pagi dan sore hari, sesuai dengan keadaan kelembaban tanah. Apabila terlihat gulma langsung dilakukan pembersihan dengan cara mencabutnya langsung dengan tangan.

\section{Pemanenan}

Panen harus dilakukan bila buah sudah cukup dianggap masak dan berumur \pm 105 hari. Panen yang kurang 


\section{JURNAL TRI $A G R O$}

tepat dapat menurunkan kualitas dari gabah maupun beras.

\section{F. Peubah Yang Diamati}

1.Tinggi tanaman (cm), 2. Jumlah anakan maksimum (anakan), 3. Jumlah anakan

\section{HASIL DAN PEMBAHASAN}

\section{A. Hasil}

Berdasarkan hasil analisis keragaman pada Tabel 2 menunjukkan bahwa pengaruh beberapa varietas padi terhadap pemberian jenis pupuk diperoleh faktor varietas padi berpengaruh sangat nyata terhadap tinggi tanaman dan jumlah gabah permalai, berpengaruh nyata terhadap berat gabah 100 butir dan barat berangkasan kering, berpengaruh tidak nyata terhadap jumlah anakan maksimum, jumlah anakan
Vol 1 No.2 Juli-Desember 2016

produktif (malai), 4. Jumlah gabah per malai (butir), 5. Jumlah gabah isi per malai 6. Persentase gabah hampa (\%), 7. Berat 100 butir (g), 8. Berat gabah kering giling (g), 9. Berat berangkasan kering $(\mathrm{g})$.

produktif, jumlah gabah isi permalai,persentase gabah hampa, dan berat GKG. Jenis pupuk berpengaruh sangat nyata terhadap jumlah anakan maksimum dan jumlah anakan produktif, berpengaruh nyata terhadap tinggi tanaman dan berat berangkasan kering, berpengaruh tidak nyata terhadap jumlah gabah permalai, jumlah gabah isi permalai, persentase gabah hampa, berat 100 butir, dan berat GKG. Interaksi berpengaruh nyata terhadap tinggi tanaman dan jumlah anakan maksimum, berpengaruh tidak nyata terhadap semua peubah yang lainnya

Tabel 2. Hasil analisis keragaman pengaruh beberapa varietas padi terhadap pemberian jenis pupuk

\begin{tabular}{|c|c|c|c|c|}
\hline \multirow[b]{2}{*}{ Peubah yang diamati } & \multicolumn{3}{|c|}{ Perlakuan } & \multirow{2}{*}{$\begin{array}{l}\text { Koefisien } \\
\text { keragaman } \\
(\%)\end{array}$} \\
\hline & $\mathrm{V}$ & $\mathrm{P}$ & $\mathrm{VxP}$ & \\
\hline Tinggi tanaman $(\mathrm{cm})$ & $* *$ & $*$ & $*$ & 4,29 \\
\hline $\begin{array}{l}\text { Jumlah anakan maksimum } \\
\text { (anakan) }\end{array}$ & $\operatorname{tn}$ & $* *$ & $*$ & 15,89 \\
\hline Jumlah anakan produktif (malai) & $\operatorname{tn}$ & $* *$ & tn & 14,66 \\
\hline Jumlah gabah per malai (butir) & $* *$ & tn & tn & 19,19 \\
\hline Jumlah gabah isi per malai (butir) & $\operatorname{tn}$ & $\operatorname{tn}$ & $\operatorname{tn}$ & 38,53 \\
\hline Persentase gabah hempa (\%) & $\operatorname{tn}$ & tn & $\operatorname{tn}$ & 30,24 \\
\hline Berat 100 butir $(\mathrm{g})$ & $*$ & tn & th & 9,00 \\
\hline Berat GKG $(g)$ & $\operatorname{tn}$ & tn & tn & 28,42 \\
\hline Berat berangkasan kering & $*$ & $*$ & $\operatorname{tn}$ & 22,79 \\
\hline
\end{tabular}

\footnotetext{
Keterangan

tn : tidak nyata

** : Nyata pada taraf uji $5 \%$

: Sangat nyata pada taraf uji $5 \%$

V : V Varietas Pađi

$\mathrm{P} \quad$ : Jenis pupuk

VxP : interaksi Varietas Padi dan Jenis Pupuk
} 


\section{JURNAL TRI $A G R O$}

\section{Tinggi Tanaman}

Hasil analisis keragaman menunjukkan bahwa perlakuan beberapa varietas berpengaruh sangat nyata terhadap tinggi tanaman, sedangkan perlakuan jenis pupuk dan interaksinya berpengauh nyata terhadap tinggi tanaman.

Hasil uji BNJ pengaruh perlakuan beberapa varietas, jenis pupuk dan interaksi pada pengukuran tinggi tanaman dapat dilihat pada Tabel 3. Perlakuan $\mathrm{V}_{2}$ berbeda sangat nyata dengan perlakuan $V_{1}$ dan $V_{3}$. Perlakuan $\mathrm{P}_{1}$ berbeda nyata dengan
Vol 1 No.2 Juli-Desember 2016

perlakuan $\mathrm{P}_{2}$, tetapi berbeda tidak nyata perlakuan $\mathrm{P}_{0}$. Sedangkan perlakuan interaksi $\mathrm{V}_{3} \mathrm{P}_{2}$ berbeda nyata dengan perlakuan interaksi lainnya, tetapi berbeda tidak nyata dengan perlakuan interaksi $\mathrm{V}_{3} \mathrm{P}_{0}$ dan $\mathrm{V}_{3} \mathrm{P}_{1}$. Rata-rata tinggi tanaman tertinggi terdapat pada perlakuan $\mathrm{V}_{3}$ dan kombinasi interaksi $\mathrm{V}_{3} \mathrm{P}_{2}$ yaitu dengan rata-rata tinggi $92,67 \mathrm{~cm}$ dan $97,33 \mathrm{~cm}$, Sedangkan tinggi tanaman paling rendah terdapat pada perlakuan $\mathrm{V}_{1}$ dan kombinasi interaksi $\mathrm{V}_{1} \mathrm{P}_{0}$ yaitu dengan rata-rata tinggi 72,88 dan $70,33 \mathrm{~cm}$.

Tabel 3. Uji lanjut BNJ Pengaruh beberapa varietas padi dan pemberian jenis pupuk pada pengukuran tinggi tanaman.

\begin{tabular}{|c|c|c|c|c|}
\hline Varietas & & Jenis Pupu & & Rata-rata \\
\hline & P0 & P1 & P2 & varietas \\
\hline V1 & $70,33 \mathrm{a}$ & $72,00 \mathrm{a}$ & $76,00 \mathrm{ab}$ & $72,88 \mathrm{a}$ \\
\hline V2 & $84,00 \mathrm{bc}$ & $87,00 \mathrm{c}$ & $87,00 \mathrm{c}$ & $92,67 \mathrm{c}$ \\
\hline V3 & $88,00 \mathrm{~cd}$ & $90,67 \mathrm{~cd}$ & $97,33 \mathrm{~d}$ & $87,33 \mathrm{~b}$ \\
\hline $\begin{array}{l}\text { Rata-rata jenis } \\
\text { pupuk }\end{array}$ & $82,66 \mathrm{ab}$ & $86,88 \mathrm{~b}$ & $81,33 \mathrm{a}$ & \\
\hline BNJ V $0,05=4,29$ & & $=4,29$ & BNJ I $0,05=10,26$ & \\
\hline
\end{tabular}

Keterangan : Angka-angka yang diikuti oleh huruf yang sama berarti berbeda tidak nyata pada uji taraf $5 \%$

\section{Jumlah Anakan Maksimum (Anakan)}

Hasil uji BNJ pengaruh perlakuan beberapa varietas dan jenis pupuk terhadap jumlah anakan maksimum dapat dilihat pada Tabel 4. Perlakuan $P_{0}$ berbeda sangat nyata dengan perlakuan $\mathrm{P}_{1}$ dan $\mathrm{P}_{2}$. Perlakuan interaksi $\quad \mathrm{V}_{3} \mathrm{P}_{0}$ berbeda nyata dengan perlakuan interaksi lainnya, tetapi berbeda tidak nyata dengan perlakuan $\mathrm{V}_{1} \mathrm{P}_{1}, \mathrm{~V}_{1} \mathrm{P} 0$, dan $\mathrm{V}_{2} \mathrm{P}_{0}$. Rata-rata jumlah anakan maksimum terbanyak terdapat pada perlakuan $\mathrm{P}_{0}$ dan kombinasi $\mathrm{V}_{3} \mathrm{P}_{0}$ yaitu dengan rata-rata 29,11 anakan dan 32,00 anakan. Sedangkan rata-rata jumlah anakan maksimum terendah terdapat pada perlakuan $\mathrm{P}_{1}$ dan perlakuan kombinasi interaksi $\mathrm{V}_{2} \mathrm{P}_{1}$ yaitu 19,44 anakan dan 17,00 anakan.

Tabel 4. Uji lanjut BNJ Pengaruh beberapa varietas padi dan pemberian jenis pupuk pada jumlah anakan maksimum.

\begin{tabular}{|c|c|c|c|c|}
\hline \multirow{2}{*}{ Varietas } & \multicolumn{3}{|c|}{ Jenis Pupuk } & \multirow{2}{*}{$\begin{array}{c}\text { Rata-rata } \\
\text { varietas }\end{array}$} \\
\hline & P0 & P1 & $\mathrm{P} 2$ & \\
\hline V1 & $26,33 \mathrm{abc}$ & $22,00 \mathrm{abc}$ & $20,00 a b$ & $22,77 \mathrm{a}$ \\
\hline V2 & $29,00 \mathrm{bc}$ & $17,00 \mathrm{a}$ & $20,33 a b$ & $22,11 \mathrm{a}$ \\
\hline V3 & $32,00 \mathrm{c}$ & $19,33 \mathrm{ab}$ & $19,00 \mathrm{ab}$ & $23,44 \mathrm{a}$ \\
\hline $\begin{array}{c}\text { Rata-rata jenis } \\
\text { pupuk }\end{array}$ & $29,11 \mathrm{~b}$ & $19,44 \mathrm{a}$ & $19,77 \mathrm{a}$ & \\
\hline BNJ V $0,05=4,33$ & & $=4,33$ & BNJ I $0,05=10,36$ & \\
\hline
\end{tabular}

Keterangan : Angka-angka yang diikuti oleh huruf yang sama berarti berbeda tidak nyata pada uji taraf $5 \%$ 


\section{Jumlah Anakan Produktif (Anakan)}

Hasil analisis keragaman menunjukkan bahwa perlakuan jenis pupuk berpengaruh sangat nyata terhadap jumlah anakan produktif. sedangkan perlakuan beberapa varietas dan interaksi berpengaruh tidak nyata terhadap jumlah anakan produktif. Hasil uji BNJ pengaruh perlakuan jenis pupuk terhadap jumlah anakan produktif dapat dilihat pada Tabel 5 . Perlakuan $\mathrm{P}_{0}$ berbeda nyata dengan perlakuan $\mathrm{P}_{1}$ dan $\mathrm{P}_{2}$, rata-rata jumlah anakan produktif terbanyak terdapat pada perlakuan $\mathrm{P}_{0}$ dan kombinasi $\quad \mathrm{V}_{3} \mathrm{P}_{0}$ yaitu dengan rata-rata 29,11 anakan dan 32,00 anakan. Sedangkan rata-rata jumlah anakan produktif terendah terdapat pada perlakuan $\mathrm{P}_{1}$ dan perlakuan kombinasi interaksi $\mathrm{V}_{2} \mathrm{P}_{1}$ yaitu 19,44 anakan dan 17,00 anakan.

Tabel 5. Uji lanjut BNJ Pengaruh beberapa varietas padi dan pemberian jenis pupuk pada perhitungan jumlah anakan produktif

\begin{tabular}{ccc}
\hline \multirow{2}{*}{ Varietas } & Rata - rata & Uji BNJ \\
\cline { 3 - 3 } & 29,11 & $0,05=4,51$ \\
\hline $\mathrm{P}_{0}$ & 19,44 & $\mathrm{~B}$ \\
$\mathrm{P}_{1}$ & 19,66 & $\mathrm{a}$ \\
$\mathrm{P}_{2}$ & $\mathrm{a}$ \\
\hline
\end{tabular}

Keterangan : Angka-angka yang diikuti oleh huruf yang sama berarti berbeda tidak nyata pada uji taraf $5 \%$

\section{Jumlah Gabah Permalai (Butir)}

Hasil analisis keragaman

menunjukkan bahwa perlakuan beberapa varietas berpengaruh sangat nyata terhadap jumlah gabah permalai. sedangkan perlakuan jenis pupuk dan interaksi berpengaruh tidak nyata terhadap jumlah gabah permalai.

Hasil uji BNJ pengaruh perlakuan varietas terhadap jumlah gabah permalai dapat dilihat pada Tabel 6. Perlakuan $\mathrm{V}_{2}$ berbeda nyata dengan perlakuan $V_{1}$ dan $V_{3}$. Rata-rata jumlah gabah permalai terbanyak terdapat pada perlakuan $\mathrm{P}_{2}$ dan kombinasi $\mathrm{V}_{2} \mathrm{P}_{2}$ yaitu dengan rata-rata 149,33 butir dan 162,67 buitr. Sedangkan rata-rata jumlah gabah permalai terendah terdapat pada perlakuan $\mathrm{P}_{0}$ dan perlakuan kombinasi interaksi $\mathrm{V}_{3} \mathrm{P}_{0}$ yaitu 120,44 butir dan 103,00 butir.

Tabel 6. Uji lanjut BNJ Pengaruh beberapa varietas padi dan pemberian jenis pupuk pada perhitungan jumlah gabah permalai

\begin{tabular}{ccc}
\hline Varietas & Rata - rata & Uji BNJ \\
\cline { 3 - 3 } & & $0,05=31,37$ \\
V1 & 120,66 & $\mathrm{~A}$ \\
V2 & 162,44 & $\mathrm{~b}$ \\
V3 & 124,33 & $\mathrm{a}$ \\
\hline
\end{tabular}

Keterangan : Angka-angka yang diikuti oleh huruf yang sama berarti berbeda tidak nyata pada uji taraf $5 \%$.

\section{Jumlah Gabah isi Permalai}

Hasil analisis keragaman menunjukkan bahwa perlakuan beberapa varietas, jenis pupuk dan interaksinya berpengaruh tidak nyata terhadap jumlah gabah permalai.

Hasil uji BNJ pengaruh perlakuan beberapa varietas, jenis pupuk, dan interaksi terhadap jumlah gabah permalai dapat dilihat pada Tabel 7. 
Tabel 7. Uji lanjut BNJ Pengaruh beberapa varietas padi dan pemberian jenis pupuk pada perhitungan jumlah gabah isi permalai

\begin{tabular}{|c|c|c|c|c|}
\hline \multirow[t]{2}{*}{ Varietas } & \multicolumn{3}{|c|}{ Jenis Pupuk } & \multirow{2}{*}{$\begin{array}{c}\text { Rata-rata } \\
\text { varietas }\end{array}$} \\
\hline & P0 & P1 & P2 & \\
\hline V1 & $70,00 \mathrm{a}$ & $57,67 \mathrm{a}$ & $72,33 \mathrm{a}$ & $66,66 \mathrm{a}$ \\
\hline $\mathrm{V} 2$ & $73,33 \mathrm{a}$ & $111,00 \mathrm{a}$ & $87,33 \mathrm{a}$ & $90,55 \mathrm{a}$ \\
\hline V3 & $68,00 \mathrm{a}$ & 65,67 a & $73,67 \mathrm{a}$ & $69,11 \mathrm{a}$ \\
\hline $\begin{array}{c}\text { Rata-rata jenis } \\
\text { pupuk }\end{array}$ & $70,44 \mathrm{a}$ & 78,11 a & 77,77 a & \\
\hline BNJ V & 34,98 & BNJ P 0,05 = 34,98 & $\mathrm{BN}$ & 83,22 \\
\hline
\end{tabular}

Keterangan : Angka-angka yang diikuti oleh huruf yang sama berarti berbeda tidak nyata pada uji taraf $5 \%$

\section{Persentase Gabah Hampa (\%)}

Hasil analisis keragaman menunjukkan bahwa perlakuan beberapa varietas, jenis pupuk dan interaksinya berpengaruh tidak nyata terhadap jumlah persentase gabah hampa.

Hasil uji BNJ pengaruh perlakuan beberapa varietas, jenis pupuk, dan interaksi terhadap persentase gabah hampa dapat dilihat pada Tabel 8 .

Tabel 8. Uji lanjut BNJ Pengaruh beberapa varietas padi dan pemberian jenis pupuk pada perhitungan persentase gabah hampa

\begin{tabular}{ccccc}
\hline Varietas & & Jenis Pupuk & & $\begin{array}{c}\text { Rata-rata } \\
\text { varietas }\end{array}$ \\
\hline V1 & P0 & P1 & P2 & $45,11 \mathrm{a}$ \\
V2 & $45,00 \mathrm{a}$ & $50,33 \mathrm{a}$ & $40,00 \mathrm{a}$ & $44,77 \mathrm{a}$ \\
V3 & $44,67 \mathrm{a}$ & $42,33 \mathrm{a}$ & $47,33 \mathrm{a}$ & $43,88 \mathrm{a}$ \\
\hline $\begin{array}{c}\text { Rata-rata jenis } \\
\text { pupuk }\end{array}$ & $34,00 \mathrm{a}$ & $54,33 \mathrm{a}$ & $43,33 \mathrm{a}$ & \\
\hline
\end{tabular}

BNJ V $0,05=16,20 \quad$ BNJ P $0,05=16,20 \quad$ BNJ I $0,05=38,58$

Keterangan : Angka-angka yang diikuti oleh huruf yang sama berarti berbeda tidak nyata pada uji taraf $5 \%$

\section{Berat Gabah 100 Butir}

Hasil analisis keragaman menunjukkan bahwa perlakuan beberapa varietas berpengaruh nyata terhadap berat gabah 100 butir. sedangkan perlakuan jenis pupuk dan interaksi berpengaruh tidak nyata terhadap berat gabah 100 butir.

Hasil uji BNJ pengaruh perlakuan jenis pupuk terhadap jumlah anakan produktif dapat dilihat pada Tabel 9 .

Tabel 9. Uji lanjut BNJ Pengaruh beberapa varietas padi dan pemberian jenis pupuk pada berat gabah 100 butir

\begin{tabular}{|c|c|c|c|c|}
\hline \multirow[t]{2}{*}{ Varietas } & \multicolumn{3}{|c|}{ Jenis Pupuk } & \multirow{2}{*}{$\begin{array}{c}\text { Rata-rata } \\
\text { varietas }\end{array}$} \\
\hline & P0 & P1 & P2 & \\
\hline V1 & $2,93 \mathrm{a}$ & $2,87 \mathrm{a}$ & $3,00 \mathrm{a}$ & $2,93 \mathrm{~b}$ \\
\hline V2 & $2,60 \mathrm{a}$ & $2,73 \mathrm{a}$ & $2,73 \mathrm{a}$ & $2,68 \mathrm{ab}$ \\
\hline V3 & $2,40 \mathrm{a}$ & $2,57 \mathrm{a}$ & $2,67 \mathrm{a}$ & $2,54 \mathrm{a}$ \\
\hline $\begin{array}{c}\text { Rata-rata jenis } \\
\text { pupuk }\end{array}$ & $2,64 \mathrm{~b}$ & $2,72 \mathrm{a}$ & $2,80 \mathrm{a}$ & \\
\hline BNJ & 0,25 & BNJ P $0,05=0,25$ & $\mathrm{BNJ}$ & 69 \\
\hline
\end{tabular}




\section{Berat Gabah Kering Giling (GKG)}

Hasil analisis keragaman menunjukkan bahwa perlakuan beberapa varietas, jenis pupuk dan interaksinya berpengaruh tidak nyata terhadap Berat
GKG. Hasil uji BNJ pengaruh perlakuan beberapa varietas, jenis pupuk, dan interaksi terhadap persentase gabah hampa dapat dilihat pada tabel 1 .

Tabel 10. Uji lanjut BNJ Pengaruh beberapa varietas padi dan pemberian jenis pupuk pada Berat GKG

\begin{tabular}{ccccc}
\hline Varietas & \multicolumn{3}{c}{ Jenis Pupuk } & $\begin{array}{c}\text { Rata-rata } \\
\text { varietas }\end{array}$ \\
\hline V1 & P0 & P1 & P2 & $37,24 \mathrm{a}$ \\
V2 & $42,97 \mathrm{a}$ & $32,47 \mathrm{a}$ & $36,30 \mathrm{a}$ & $41,67 \mathrm{a}$ \\
V3 & $44.97 \mathrm{a}$ & $40,93 \mathrm{a}$ & $39,13 \mathrm{a}$ & $35,68 \mathrm{a}$ \\
\hline $\begin{array}{c}\text { Rata-rata jenis } \\
\text { pupuk }\end{array}$ & $49,20 \mathrm{a}$ & $27,63 \mathrm{a}$ & $30,23 \mathrm{a}$ & \\
\hline \multicolumn{2}{c}{ BNJ V $0,05=13,03$} & $33,67 \mathrm{a}$ & $35,22 \mathrm{a}$ & \\
\hline
\end{tabular}

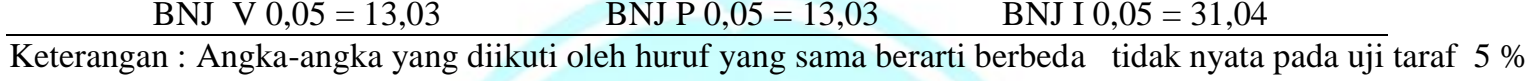

Perlakuan $\mathrm{V}_{3}$ berbeda nyata dengan

\section{Berat Berangkasan Kering (Gram)}

Hasil analisis keragaman menunjukkan bahwa perlakuan beberapa varietas dan jenis pupuk berpengaruh nyata terhadap berat berangkasan kering. Sedangkan interaksi berpengaruh tidak nyata terhadap berat berangkasan kering.

Hasil uji BNJ pengaruh perlakuan jenis pupuk terhadap berat berangkasan kering dapat dilihat pada Tabel 11. perlakuan $V_{1}$ dan $V_{2}$. Perlakuan $P_{0}$ berbeda nyata dengan perlakuan $\mathrm{P}_{1}$ dan $\mathrm{P}_{2}$. Ratarata berat berangkasan kering terberat terdapat pada perlakuan $\mathrm{V}_{3}$ dan kombinasi $\mathrm{V}_{3} \mathrm{P}_{0}$ yaitu dengan rata-rata 87,19 gr dan 93,74 gr. Sedangkan rata-rata berat berangkasan kering teringan terdapat pada perlakuan $\mathrm{P}_{2}$ dan perlakuan kombinasi interaksi $\mathrm{V}_{1} \mathrm{P}_{2}$ yaitu 60,62 gr dan 43,04 gr.

Tabel 11. Uji lanjut BNJ Pengaruh beberapa varietas padi dan pemberian jenis pupuk pada berat berangkasan kering

\begin{tabular}{ccc}
\hline \multirow{2}{*}{ Varietas } & Rata - rata & Uji BNJ \\
\cline { 3 - 3 } & & $0,05=31,37$ \\
\hline $\mathrm{P}_{0}$ & 79,8 & $\mathrm{~B}$ \\
$\mathrm{P}_{1}$ & 77,92 & $\mathrm{~b}$ \\
$\mathrm{P}_{2}$ & 60,62 & $\mathrm{a}$ \\
\hline
\end{tabular}

Keterangan : Angka-angka yang diikuti oleh huruf yang sama berarti berbeda tidak nyata pada uji taraf $5 \%$

\section{B. Pembahasan}

Hasil analisis sifat kimia tanah pada tanah pasang surut yang dilakukan sebelum penelitian dan berdasarkan kriteria Pusat Penelitian Tanah (1983), tanah yang digunakan pada penelitian ini tergolong masam $\left(\mathrm{pH} \mathrm{H}_{2} \mathrm{O}=4,72\right)$ dengan kapasitas tukar kation tergolong sedang $(35,74$ $\left.\mathrm{cmol}_{(+)} \mathrm{kg}^{-1}\right)$, kandungan C-organik 83,50 $\mathrm{g} \mathrm{kg}^{-1}$ tergolong sangat tinggi, kandungan $\mathrm{N}$ total tergolong sedang dan $\mathrm{P}$ tersedia tergolong sangat tinggi $\left(3,9 \mathrm{~g} \mathrm{~kg}^{-1}\right.$ dan $148,39 \mathrm{mg} \mathrm{kg}^{-1}$ ), basa tertukar seperti Cadd 15,62 $\mathrm{cmol}_{(+)} \mathrm{kg}^{-1}$ tergolong tinggi, $\mathrm{Mg}$ dd 5,91 $\mathrm{cmol}_{(+)} \mathrm{kg}^{-1}$ tergolong tinggi, K-dd $0,77 \mathrm{cmol}_{(+)} \mathrm{kg}^{-1}$ tergolong tinggi, Na-dd $0,68 \mathrm{cmol}_{(+)} \mathrm{kg}^{-1}$ tergolong tinggi, dengan Kejenuhan Basa 63,36 \% tergolong tinggi, $\mathrm{Fe} 135,12 \mathrm{mg} \mathrm{kg}^{-1}$, dengan tekstur tanah 


\section{JURNAL TRI $A G R O$}

mengandung $25,93 \%$ pasir, $36,48 \%$ debu, dan $37,59 \%$ liat dan tergolong tekstur tanah lempung beriat.

Tanah pasang surut yang digunakan pada penelitian ini tergolong tanah yang memiliki kesuburan tanah rendah, hal ini disebabkan karena $\mathrm{pH}$ tanah tergolong masam yaitu ber-pH 4,72. Reaksi tanah menunjukkan sifat kemasaman atau alkalinitas tanah yang dinyatakan dengan nilai $\mathrm{pH}$. Nilai $\mathrm{pH}$ menunjukkan banyaknya konsentrasi ion hydrogen $(\mathrm{H}+)$ di dalam tanah (Kirnadi et al.2014)

Menurut Foth (1998), pengaruh terbesar yang umum dari $\mathrm{pH}$ terhadap tanaman adalah pengaruhnya terhadap ketersediaan unsur hara di dalam tanah. Lebih lanjut Hardjowigeno (1989) menyatakan arti pentingnya $\mathrm{pH}$ tanah adalah sebagai berkut : (1) menentukan mudah tidaknya unsur-unsur hara diserap tanaman. Pada umumnya unsur hara mudah diserap akar tanaman pada $\mathrm{pH}$ tanah sekitar netral, (2) menunjukkan kemungkinan adanya unsur-unsur beracun. Pada tanah masam banyak ditemukan ion-ion $\mathrm{Al}$ di dalam tanah, selain memfiksasi unsur hara $\mathrm{P}$ juga merupakan racun bagi tanaman. Pada tanahtanah rawa (termasuk pasang surut) $\mathrm{pH}$ yang terlalu rendah menunjukkan sulfat yang tinggi, merupakan racun bagi tanamandan (3) mempengaruhi perkembangan mikro organisme. Bakteri nitrifikasi hanya dapat berkembang dengan baik pada $\mathrm{pH}$ lebih dari 5,5 .

Selain itu kapasitas tukar kation pada tanah pasang surut ini tergolong sedang $\left.\left(35,74 \mathrm{cmol}_{+}\right) \mathrm{kg}^{-1}\right)$. Kapasitas tukar kation atau kemampuan tanah menyerap unsurunsur kation yang dibutuhkan tanaman pada tanah ini tergolong sedang. Sedangnya nilai KTK ini disebabkan oleh stabilnya kandungan bahan organik pada tanah yang berupa humus pada lapisan atas relatif masih tinggi yang dicirikan oleh kandungan $\mathrm{C}$ organik tinggi $\left(83,50 \mathrm{~g} \mathrm{~kg}^{-1}\right.$ atau $\left.8,35 \%\right)$

\section{Vol 1 No.2 Juli-Desember 2016}

Tanah yang memiliki KTK tinggi dapat memegang unsur hara yang ada dan unsur hara yang berasal dari pupuk, sehingga pupuk yang diberikan tidak mudah tercuci dan dapat tersedia kembali bagi tanaman.

Hasil penelian terlihat bahwa varietas jatiluhur menunjukan pertumbuhan dan produksi lebih baik bila dibandingkan dengan varietas lain. Hal ini dapat dilihat pada peubah yang diamati tinggi tanaman $(92,67 \mathrm{~cm})$, gabah permalai $\quad(162,44$ butir), gabah isi permalai (90,55 butir), dan berat GKG (41,67 gr). Hasil ini disebabkan bahwa varietas jatiluhur lebih respon dan beradaptasi dengan tanah pasang surut bila dibandingkan dengan varietas lain, hal ini didukung oleh jumlah gabah per malai dan gabah isi per malai yang terbukti lebih banyak sehingga dapat mempengaruhi berat GKG lebih berat.

Varietas inpago 7 menunjukan pertumbuhan dan produksi terendah dibandingkan varietas lain. Hal ini dapat dilihat dari peubah yang diamati Berat seratus butir (2,54 gr), dan Berat GKG $(35,68)$. Hasil ini sebabkan varietas inpago 7 tidak respon dan beradaptasi dengan tanah pasang surut bila dibandingkan dengan varietas lain.

Pemberian pupuk anorganik menunjukan pertumbuhan dan produksi yang lebih baik dibandingkan dengan pemberian pupuk hayati dan pupuk kompos jerami padi. Hal ini dapat dilihat pada peubah yang diamati jumlah anakan produktif ( 29,11 anakan), berat berangkasan kering ( $79,8 \mathrm{gr}$ ), dan berat GKG tertinggi (45,71 gr). Hasil ini karena pupuk anorganik lebih cepat menyediakan unsur hara N, P, $\mathrm{K}$ bagi tanaman padi, sehingga dapat mempengaruhi pertumbuhan dan produksi tanaman padi.

Unsur hara nitrogen dapat merangsang pertumbuhan vegetatif tanaman seperti tinggi tanamandan jumlah anakan, 


\section{JURNAL TRI $A G R O$}

sedangkan penambahan unsur hara $\mathrm{P}$ akan menguatkan sistem perakaran tanaman sehingga dihasilkan anakan produktif yang banyak (Hidayati, 2010). Sedangkan peningkatan nilai berat gabah kering giling dipengaruhi oleh unsur hara $\mathrm{N}$, karena nitrogen merupakan komponen penting dari klorofil yang memberikan warna hijau pada daun yang diperlukan dalam proses fotosintesis. Dengan meningkatnya proses fotosintesis, maka hasil tanaman juga akan meningkat (Aprianto, 2012).

Dari hasil produksi menunjukkan bahwa pemberian pupuk anorganik memberikan produksi GKG lebih tinggi bila dibandingkan dengan pemberian pupuk hayati karena pupuk anorganik lebih cepat menyedia unsur hara bagi tanaman, namun pemberian pupuk kompos jerami padi memberikan hasil produksi GKG lebih rendah bila dibandingkan dengan pemberian pupuk hayati karena pupuk kompos jerami padi harus mengalami proses dekomposisi terlebih dahulu sedangkan pupuk hayati yang berikan sebanyak 5 kali mampu mendekomposisi lebih cepat bahan organik yang ada di dalam tanah,sehingga unsur hara lebih cepat tersedia.

Untuk budidaya padi secara terus menerus pupuk hayati dan pupuk kompos jerami padi lebih baik digunakan karena dapat memperbaiki sifat fisik dan kimia tanah, sedangakan pupuk anorganik bila digunakan secara terus menerus akan menyebabkan tanah kerusakan fisik dan kimia tanah. Kombinasi antara varietas jatiluhur dan pupuk anorganik memberikan pertumbuhan dan produksi lebih baik bila dibandingkan dengan kombinasi yang lain. Hal ini dapat lihat pada peubah jumlah anakan maksimum (32 anakan), jumlah anakan produktif (32 anakan), berat berangkasan kering $(93,74$ gr), dan Berat GKG (49,20 gr). Hal ini sebabkan oleh varietas jatiluhur dan pupuk anorganik merupakan kombisi yang positif karena

\section{Vol 1 No.2 Juli-Desember 2016}

varietas jatiluhur sangat respon dengan pemupukan anorganik.

\section{KESIMPULAN DAN SARAN}

\section{A. Kesimpulan}

1. Varietas padi jatiluhur menunjukan pertumbuhan dan produksi yang lebih baik dibandingkan dengan varietas lain seperti tinggi tanaman, gabah permalai, gabah isi permalai dan berat GKG.

2. Pemberian pupuk anorganik menunjukan pertumbuhan dan produksi yang lebih baik dibandingkan dengan pemberian pupuk hayati dan pupuk kompos jerami padi, seperti jumlah anakan maksimum, jumlah anakan produktif, berat berangkasan kering, dan berat GKG tertinggi.

3. Varietas padi jatiluhur dan jenis pupuk anorganik mununjukan perumbuhan yang baik, seperti tinggi tanaman dan jumlah anakan maksimum.

\section{B. Saran}

1. Perlunya dilakukan penelitian lanjutan mengenai pengunaan varietas jatiluhur di tanah pasang surut tipe $\mathrm{C}$.

2. Pada penelitian ini tetap diperlukan pupuk organik (Pupuk hayati dan kompos jerami padi).

\section{DAFTAR PUSTAKA}

BPS Banyuasin. 2012. Banyuasin Dalam Angka 2012.Badan Pusat Statistik KabupatenBanyuasin.Http://banyuasi nkab.bps.go.id/images/publikasi_201 2/banyuasin\%20dalam\%20angka\%2 02012/index.html

BPS OKUT. 2012. Ogan Komering Ulu dalam Angka Tahun 2012.Badan Pusat Statistik Kabupaten Ogan 
JURNAL TRI $A G R O$

Komering Ulu Timur.

Http://okutimurkab.bps.go.id/images/ Publikasi/dda2012/index.htm.

BPS Sumsel.2012. Sumatera Selatan dalam Angka Tahun 2012. Badan Pusat Statistik Provinsi Sumatera Selatan. Http://sumsel.bps.go.id/ images/publikasi/flipping/sumsel\%2 Odalam\%20angka\%202012/DDA201 2.htm

Nusyirwan Hasan, Adri, Azwar, Firdaus. 2003. Keragaaan varietas Batang Hari pada lahan pasang surut sulfat masam potensial. Temu Aplikasi dan Seminar Teknologi Pertanian Di Lahan Pasang Surut Kalimantan Tengah 2003

Nazemi, N., A. Hairani dan Nurita . 2012. Optimalisasi pemanfaatan lahan rawa pasang surut melalui pengelolaan lahan dan komuditas. Balai Penelitian Pertanian Lahan Rawa (Balittra).

Salikin, K.A. 2003. Sistem Pertanian Berkelanjutan. Kanisius. Yogyakarta.

Nyoman P. Aryantha.2010. Kompos.Pusat Penelitian Antar Universitas Ilmu Hayati LPPM-ITB. Dept. Biologi FMIPA-ITB.diakses dari http://www.id.wikipedia.org Wiki/kompos.

Widjaja-Adhi,IPG, Nugroho dan S.Karama, Didi Ardi 1992. Sumberdaya lahan rawapotensi, kebutuhan dan Pemanfaatan Dalam Risalah Pertemuan Nasional Pengembanagan Pertanian Lahan Rawa Pasang Surut dan Lebak. Cisarua, 3-4 Maret 1992

Anonimus. 2013. Pemanfaatan Jerami Padi Sebagai Pupuk Organik. Balai pengkajian Teknologi Pertanian Jawa Barat.

Rauf, A., W, Syamsuddin, dan Sihombing, S., R. 2000. Peranan Pupuk NPK Pada Tanaman Padi. Badan Penelitian dan Pengembangan Pertanian. Irian Jaya.
Vol 1 No.2 Juli-Desember 2016

Gofar, N., dan Marsi. 2010. Penyebab Paket Teknologi Pupuk Organik Hayati Untuk Mendukung Pertanian Ramah Lingkungan, Laporan Penelitian Strategis Nasional, Lembaga Penelitian UNSRI, Indralaya.

Anonimus. 2010. Varietas padi Aek Sibundong. Bank Pengatuan Tanaman Pangan Indonesia.

Marlina, N,. R.I.S Aminah and B.D Wanata. 2013. Pemanfaatan Beberapa Jenis Pupuk Hayati pada Beberapa Varietas Padi (Oryza sativa L.) di Lahan Pasang Surut. Seminar Nasional Lahan Suboptimal.

Anonimus. 2012. Inpogo 7 beras merahnya pagi gogo. Badan Litbang Pertanian.

Kirnadi, J, A., A, Zuraida, dan Ilhamiyah. 2014. Survei status kesuburan tanah di lahan usahatani padi lahan pasang surut kabupaten banjar. Media Sains.

Foth, H. D. 1998. Dasar-dasar ilmu tanah. Penerbit Gadjah Mada University Press. Yogyakarta. 